\title{
SIMULASI PERBANDINGAN TITIK JEPIT TIANG MENGGUNAKAN VIRTUAL FIXED POINT DAN LATERAL SPRING DI DERMAGA "KNP"
}

\author{
Andree Savio ${ }^{1}$ dan Sunarjo Leman ${ }^{2}$ \\ ${ }^{1}$ Program Studi Sarjana Teknik Sipil, Universitas Tarumanagara, Jl. Letjen S. Parman No.1 Jakarta \\ andree.325170046@stu.untar.ac.id \\ ${ }^{2}$ Program Studi Sarjana Teknik Sipil, Universitas Tarumanagara, J1. Letjen S. Parman No.1 Jakarta \\ sunarjo@ft.untar.ac.id
}

Masuk: 04-07-2021, revisi: 25-08-2021, diterima untuk diterbitkan: 30-08-2021

\begin{abstract}
The jetty is the most important facility in the port because it is connected between the sea and the land. The jetty structure consists of the upper structure (beams, plates and pile caps) and the lower structure (piles). The upper structure uses reinforced concrete as the base material and the lower structure can use steel or concrete material. In designing the piles on the jetty, the depth of the fixed point is not at the seabed depth, but below the seabed. It is necessary to conduct research on the depth of the pile fixed point at KNP jetty Southeast Sulawesi. Based on the OCDI 2002 (Overseas Coastal Area Development Institute of Japan) using the virtual fixed point method (1/ $\beta$ ), the depth of the fixed point on the KNP jetty is $24 \mathrm{~m}$, meanwhile according to the lateral spring method the KNP jetty has a fixed point depth of 25,6 m. and by adding a lateral spring to the pile in the virtual fixed point method, it can also make the model more efficient with a smaller deflection of 6,43\% for deflection due to earthquake in the $x$ direction and 7,25\% for deflection due to earthquake in y direction.
\end{abstract}

Keyword: virtual fixed point; lateral spring; jetty; depth comparison; deflection comparison.

\begin{abstract}
ABSTRAK
Dermaga merupakan fasilitas yang paling penting pada pelabuhan karena menghubungkan antara laut dan daratan. Struktur dermaga terdiri dari struktur atas (balok, pelat dan pile cap) dan struktur bawah (tiang pancang). Struktur atas menggunakan bahan dasar beton bertulang dan struktur bawah dapat menggunakan bahan baja atau beton. Dalam mendesain tiang pancang pada dermaga, kedalaman titik jepit tidak berada pada kedalaman seabed tetapi berada dibawah seabed. Perlu dilakukan penelitian tentang kedalaman titik jepit tiang pancang. Studi kasus yang dibahas pada penelitian ini adalah dermaga yang berlokasi di Kendari, Sulawesi Tenggara. Dermaga tersebut dikenal dengan nama dermaga "KNP". Berdasarkan OCDI (Overseas Coastal Area Development Institute of Japan) tahun 2002 dengan menggunakan metode virtual fixed point $(1 / \beta)$ memiliki kedalaman titik jepit pada dermaga "KNP" sebesar $24 \mathrm{~m}$, sedangkan menurut metode pegas lateral pada dermaga "KNP" memiliki kedalaman titik jepit sebesar 25,6 m dan dengan menambahkan pegas lateral pada tiang pancang dalam metode virtual fixed point juga dapat membuat model lebih efisien dengan defleksi yang lebih kecil sebesar 6,43\% untuk defleksi akibat gempa arah x dan 7,25\% untuk defleksi akibat gempa arah y.
\end{abstract}

Kata Kunci: virtual fixed point; lateral spring; dermaga; perbandingan kedalaman; perbandingan defleksi.

\section{PENDAHULUAN}

Dermaga adalah sebutan umum untuk bangunan penambat kapal, yang berfungsi juga untuk bongkar muat barang maupun penumpang (Irawati, 2019). Dermaga merupakan fasilitas yang paling penting pada pelabuhan karena menghubungkan antara laut dan daratan. Sebagai tempat sandaran kapal, dermaga merupakan fasilitas yang secara aktif terus menerima gaya yang besar, baik dari kapal tersebut maupun dari pengaruh lingkungan perairan. Struktur dermaga harus didesain kuat (Gustinara, 2013). Beban yang bekerja pada dermaga umumnya terdiri dari 4 jenis. Beban mati (dead load), merupakan berat yang berasal dari struktur sendiri, contohnya balok, tiang pancang, dan pelat pantai. Beban mati tambahan, merupakan berat yang berasal dari elemen tambahan pada struktur bangunan secara permanen, contohnya fender dan bollard. Beban hidup (live load), merupakan beban yang dapat bergerak dan bersifat sementara, contohnya adalah crane, truck, dan peralatan bongkar muat. Gaya benturan kapal (berthing forces), pada waktu merapatkan kapal pada dermaga, setiap tipe dan masing-masing kapal mempunyai kecepatan saat bersandar sehingga terjadi benturan antara dermaga dan kapal. Kecepatan kapal saat bersandar sangat bergantung dari massa kapal, 
kondisi perairan di lokasi dermaga, dan ukuran kapal. Besaran energi benturan diberikan pada Persamaan 1 (Triatmodjo, 2010).

$$
E=\frac{w v^{2}}{2 g} C m C e C s C c
$$

Dengan $E=$ energi benturan $(\mathrm{t} \mathrm{m}), V=$ komponen tegak lurus sisi dermaga dari kecepatan kapal pada saat membentur dermaga $(\mathrm{m} / \mathrm{d}), w=$ displacement (berat) kapal, $g=$ percepatan gravitasi $\left(\mathrm{m} / \mathrm{d}^{2}\right), C m=$ koefisien massa $C e=$ koefisien eksentrisitas $C s=$ koefisien perkerasan $C c=$ koefisien bentuk dari tambatan.

Koefisien massa tergantung pada gerakan air di sekeliling kapal, yang dapat dihitung pada Persamaan 2 dan 3 (Triatmodjo, 2010).

$$
\begin{aligned}
& C m=1+\frac{\pi}{2 C b} \frac{d}{B} \\
& C b=\frac{W}{L p p B d \gamma_{0}}
\end{aligned}
$$

Koefisien eksentrisitas adalah perbandingan antara energi sisa dengan energi kinetik kapal yang berapat, dan dapat dihitung dengan Persamaan 4 (Triatmodjo, 2010).

$$
\mathrm{Ce}=\frac{1}{1+\left(\frac{l}{r}\right)^{2}}
$$

Dengan $l=$ jarak sepanjang permukaan air dermaga pada pusat berat kapal sampai pada titik sandar kapal, $r=$ jari-jari putaran disekeliling pusat berat kapal pada permukaan air.

Titik kontak pertama antara kapal dengan dermaga adalah suatu titik dari 1/4 panjang kapal dengan dermaga dan 1/3 panjang kapal dengan dolphin, dan nilai I dapat dihitung dengan menggunakan Persamaan 5 dan 6 (Triatmodjo, 2010).

$$
\begin{gathered}
\text { I dermaga }=1 / 4 \text { Loa } \\
I \text { dolphin }=1 / 6 \text { Loa }
\end{gathered}
$$

Gaya tarikan kapal pada alat tambat yang disebabkan oleh tiupan angin dan arus pada badan kapal disebut dengan gaya tambat (mooring forces). Angin yang bertiup ke arah kapal yang sedang di tambatkan dapat mengakibatkan gerakan kapal yang menyebabkan gaya pada dermaga. Jika arah angin nya menuju dermaga, maka gaya tersebut berupa gaya benturan ke dermaga sedangkan jika arah angin nya meninggalkan dermaga akan menyebabkan gaya tarikan kapal pada alat penambat. Besar gaya angin tergantung pada arah dan kecepatan hembus angin. Jika angin datang dari arah haluan $\left(\alpha=0^{\circ}\right)$, maka gaya longitudinal dapat dihitung dengan Persamaan 7. Jika angin datang dari arah buritan $\left(\alpha=180^{\circ}\right)$, maka gaya longitudinal dapat dihitung dengan Persamaan 8. Jika angin datang dari arah lebar $\left(\alpha=90^{\circ}\right)$, maka gaya longitudinal dapat dihitung dengan Persamaan 9 (Triatmodjo, 2010).

$$
\begin{array}{r}
R w=0.42 \text { Qa Aw } \\
R w=0.50 \text { Qa Aw } \\
R w=1.10 \text { Qa Aw } \\
Q a=0.063 V^{2}
\end{array}
$$

Dengan $R w=$ gaya akibat angin $(\mathrm{kg}), V=$ kecepatan angin $(\mathrm{m} / \mathrm{d}), A w=$ proyeksi bidang yang tertiup angin $\left(\mathrm{m}^{2}\right)$, $Q a=$ tekanan angin $\left(\mathrm{kg} / \mathrm{m}^{2}\right)$.

Besar gaya yang ditimbulkan oleh arus diberikan oleh Persamaan 11 (The Overseas Coastal Area Development Institute of Japan, 2002).

$$
F D=0,5 C d A v^{2} \rho o
$$

Dengan $C D=$ koefisien drag coefficient, $\rho o=$ massa jenis air laut, $A=$ luasan tiang yang terproyeksi $\left(\mathrm{m}^{2}\right)$, $v=$ kecepatan arus $(\mathrm{m} / \mathrm{s})$.

Kapal yang merapat di sepanjang dermaga akan berhenti sebagian dengan menggunakan mesinnya sendiri dan sebagian ditahan oleh tali penambat yang dililitkan pada bollard, maka bollard harus mampu menahan gaya tarikan, yang paling tidak sama dengan gaya yang bisa memutuskan tali penambat. Dimensi bollard dan pengangkerannya pada dermaga harus direncanakan sedemikian sehingga mampu menahan gaya. Gaya akibat bollard dapat ditentukan dengan menggunakan Tabel 1 (Triatmodjo, 2010). 
Tabel 1 Gaya Bollard dan jarak antara Bollard

\begin{tabular}{ccccc}
\hline $\begin{array}{c}\text { Berat kapal } \\
\text { (ton) }\end{array}$ & $\begin{array}{c}\text { Gaya bollard } \\
(\mathrm{kN})\end{array}$ & $\begin{array}{c}\text { Jarak antara bollard } \\
(\mathrm{m})\end{array}$ & $\begin{array}{c}\text { Gaya bollard tegak lurus } \\
\text { tambatan }(\mathrm{kN} / \mathrm{m})\end{array}$ & $\begin{array}{c}\text { Gaya bollard sepanjang } \\
\text { tambatan }(\mathrm{kN} / \mathrm{m})\end{array}$ \\
\hline 2.000 & 100 & $5-10$ & 15 & 10 \\
5.000 & 200 & $10-15$ & 15 & 10 \\
10.000 & 300 & 15 & 20 & 15 \\
20.000 & 500 & 20 & 25 & 20 \\
30.000 & 600 & 20 & 30 & 20 \\
50.000 & 800 & $20-25$ & 35 & 20 \\
100.000 & 1.000 & 25 & 40 & 25 \\
200.000 & 1.500 & 30 & 50 & 30 \\
\hline
\end{tabular}

(Sumber: Triatmodjo, 2010)

Gaya akibat gempa dapat dihitung menggunakan SNI 1726:2019 (tata cara perencanaan gempa untuk bangunan gedung dan nongedung). Untuk menghitung besaran gaya lateral di dasar struktur, dapat dihitung dengan menggunakan Persamaan 12.

$$
V=W \times C S
$$

Dengan $V=$ gaya lateral desain total di dasar struktur $(\mathrm{kN}), W=$ berat struktur, dan $C s=$ koefisien gempa dasar.

Struktur dermaga merupakan struktur bangunan yang dibuat di atas perairan yang menghubungkan bagian darat dan terdiri dari bangunan atas, contohnya balok, pelat lantai dan bangunan bawah yang terdiri dari fondasi tiang pancang untuk mendukung bangunan yang berada di atasnya (Sulardi, 2018). Fondasi tiang pancang di dermaga pada umumnya didesain dengan menggunakan metode virtual fixed point $(1 / \beta)$. Kedalaman titik jepit tiang pancang di dermaga berada sebesar $1 / \beta$ di bawah permukaan virtual. Fondasi tiang pancang harus didesain dengan memperhitungkan beban vertikal dan beban lateral. Penelitian ini akan melakukan simulasi untuk mendapatkan hasil yang optimal dengan membandingkan kedalaman titik jepit tiang pancang di dermaga "KNP” Kendari, Sulawesi Tenggara, dengan sistem perletakan virtual fixed point dan lateral spring.

\section{Virtual fixed point}

Untuk melakukan analisis kedalaman titik jepit dermaga perlu diasumsikan kedalaman titik jepit di bawah seabed. Asumsi titik jepit ini bertujuan agar dapat melakukan perhitungan untuk mendapatkan panjang tiang permodelan. Dengan menggunakan metode virtual fixed point, tiang pancang diasumsikan berada pada kedalaman $1 / \beta$ dibawah permukaan virtual ground. virtual ground dapat dilihat pada Gambar 1

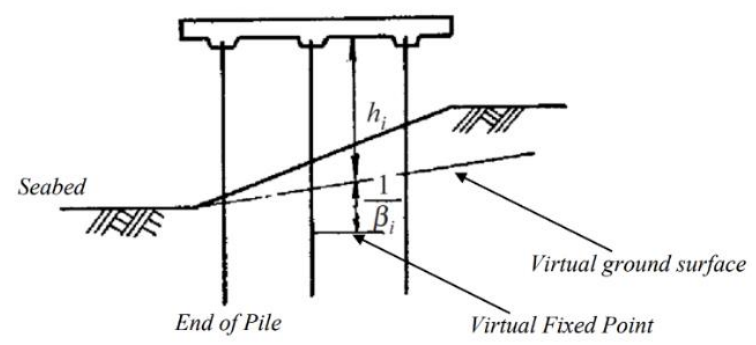

Gambar 1 Virtual ground surface (The Overseas Coastal Area Development Institute of Japan, 2002)

Perhitungan untuk kedalaman virtual fixed point $(\beta)$ dapat dihitung dengan Persamaan 13 dan 14 (OCDI, 2002).

$$
\begin{aligned}
& K h=1,5 N \\
& \beta=\sqrt[4]{\frac{k_{h} D}{4 E I}}
\end{aligned}
$$

Dengan $K h=$ faktor koefisien dari reaksi dasar pondasi dan $N=$ nilai pukulan rata-rata pada N-SPT dari seabed sampai pada titik kedalaman borlog. $D=$ diameter tiang, $E=$ modulus elastis tiang, dan $I=$ momen inersia penampang tiang. 
Besarnya nilai kekakuan yang diberikan oleh tanah pada tiang pancang berpengaruh terhadap ukuran tiang pancang yang digunakan, kedalaman lapisan tanah, dan nilai N-SPT dari tanah tersebut. Dalam permodelan dengan software, kondisi tanah akan dimodelkan dengan media pegas secara lateral. Pegas tersebut dimodelkan pada tiang setiap n meter. Besarnya nilai spring lateral dapat dicari dengan menggunakan Persamaan 15 (Bowles, 1997).

$$
K i=K s A
$$

Dengan $K i=$ nilai koefisien spring (ton $/ \mathrm{m}), K s=$ koefisien tahanan lateral (ton $\left./ \mathrm{m}^{3}\right), A=$ luas selimut tiang pancang $\left(\mathrm{m}^{2}\right)$. Nilai koefisien tahanan lateral tanah $(K s)$ dicari dengan mengkonversi nilai N-SPT menjadi nilai qu (unconfined compression strength) yang dapat dilihat pada Tabel 2.

Tabel 2 Perkiraan nilai korelasi antara N-SPT dan qu

\begin{tabular}{ccc}
\hline Standard penetration number $(N)$ & Consistency & $\begin{array}{c}\text { Unconfined compression strength, qu } \\
\left(\mathrm{kN} / \mathrm{m}^{2}\right)\end{array}$ \\
\hline$<2$ & Very soft & $<25$ \\
$2-8$ & Soft to medium & $25-80$ \\
$8-15$ & Stiff & $80-150$ \\
$15-30$ & Very stiff & $150-400$ \\
$>30$ & Hard & $>400$ \\
\hline
\end{tabular}

(Sumber: DAS, 2011)

Setelah mengubah nilai N-SPT menjadi qu (unconfined compression strength), maka selanjutnya menggunakan nilai $q u$ tersebut untuk mendapatkan nilai koefisien tahanan lateral tanah $(K s)$. Nilai koefisien tahanan lateral tanah dapat dilihat pada Gambar 2. untuk mencari nilai koefisien tahanan lateral tanah $(K s)$.

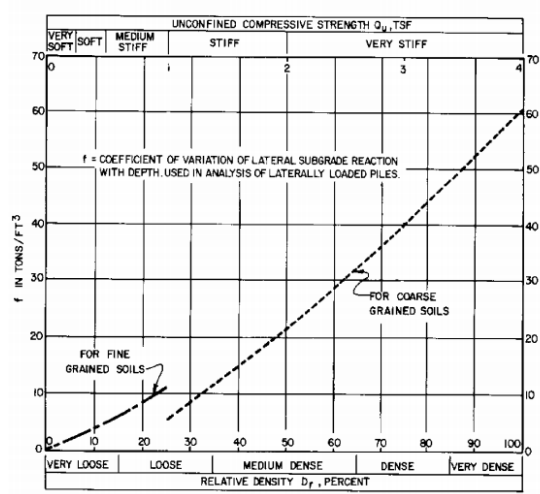

Gambar 2 Grafik coefficient of variation of subgrade reaction (NAVFAC, 1971)

Setelah mendapatkan nilai pegas horisontal, langkah selanjutnya adalah menghitung konstanta pegas vertikal $(K v)$. $K v$ dipakai untuk menghitung besarnya reaksi pada kepala tiang atau besarnya penurunan elastis (elastic settlement). Untuk memperkirakan besarnya penurunan dapat menggunakan perkiraan berdasarkan kurva beban penurunan (load settlement curve) dari percobaan pembebanan vertikal pada tiang. Tetapi untuk pemakaian praktis, hal ini dilakukan berdasarkan perhitungan dengan memakai konstanta tanah atau secara empiris dengan memakai cara statistic berdasarkan data dari percobaan pembebanan. Sebagai contoh, Persamaan 16 adalah cara empiris yang dipakai untuk jalan raya di Jepang. Jika tiang yang terbuat dari pipa baja maka $a$ dihitung dengan Persamaan 17. Jika tiang beton pratekan (prestressed concrete) maka $a$ dihitung dengan Persamaan 18. Jika tiang yang dicor di tempat maka $a$ dihitung dengan Persamaan 19. (Apriliawati, 2017).

$$
\begin{gathered}
K v=a \frac{A p \cdot E p}{l} \\
a=0,027(l / D)+0,2 \\
a=0,041(l / D)-0,27 \\
a=0,022(l / D)-0,05
\end{gathered}
$$

Dengan $A p=$ luas penampang netto dari tiang $\left(\mathrm{cm}^{2}\right), E p=$ modulus elastisitas tiang $\left(\mathrm{kg} / \mathrm{cm}^{2}\right), l=$ panjang tiang $(\mathrm{cm})$ $D=$ diameter tiang $(\mathrm{cm})$. Rumus di atas dapat dipakai bila $/ / D \geq 10$. 


\section{METODE PENELITIAN}

Kondisi pembebanan dan alam pada suatu tempat dapat mempengaruhi suatu bangunan maka perlu data yang cukup akurat untuk menganalisis dermaga. Data proyek yang digunakan untuk melakukan simulasi kedalaman titik jepit tiang pancang menggunakan data pembangunan dermaga "KNP” pada tahun 2016.

Penelitian ini menggunakan program midas gen 2021 dan desain struktur dermaga mengacu pada peraturan-peraturan antara lain, OCDI (2002) Technical Standards and Commentaries for Port and Harbour Facilities in Japan dan SNI 1726:2019 mengenai tata cara perencanan ketahanan gempa untuk struktur bangunan gedung dan nongedung.

Kombinasi pembebanan mengacu pada unified facilities criteria (UFC) 4-152-01.

Data-data yang digunakan untuk menganalisis adalah sebagai berikut:

1. Lokasi proyek: Kota Kendari Propinsi Sulawesi Tenggara.

2. Data pasang surut untuk desain perencanaan pada dermana "KNP" menggunakan nilai $H W S=+2,80 \mathrm{~m}$; $M S L=+1.40 \mathrm{~m}$; dan $L W S= \pm 0,00 \mathrm{~m}$.

3. Data tanah digunakan adalah borelog 1 dari 2 data borelog pada lokasi.

4. Jenis material yang digunakan adalah

a. Tiang pancang baja menggunakan standar SKK41/ SS 400/ ASTM A252 (Gr.3) dengan menggunakan 3 jenis ukuran diameter yaitu $711 \mathrm{~mm}$ dengan tebal $14 \mathrm{~mm}, 1016 \mathrm{~mm}$ dengan tebal $16 \mathrm{~mm}$, dan 1200 mm dengan tebal $19 \mathrm{~mm}$.

b. Beton bertulang

Mutu beton yang digunakan adalah $35 \mathrm{Mpa}$ dengan berat jenis beton adalah $2400 \mathrm{~kg} / \mathrm{m}^{3}$.

c. Tulangan baja

Tulangan baja menggunakan Fy (yield strength) deform-BJTD 40 (400 Mpa) dan Fu (Ultimate tensile) deform-BJTD 40 (600 Mpa).

Pembebanan yang digunakan adalah:

1. Beban mati (dead load) untuk beton bertulang adalah $2400 \mathrm{~kg} / \mathrm{m} 3$ dan untuk baja adalah $7850 \mathrm{~kg} / \mathrm{m} 3$.

2. Beban mati tambahan/Superimposed dead load (SDL) adalah berat dari fender dan bollard.

3. Beban hidup yang direncanakan untuk dermaga ini yaitu $3 \mathrm{ton} / \mathrm{m}^{3}$ yang diperoleh dari Laporan Perencanaan Dermaga “KNP”, 2016.

4. Beban berthing $(\mathrm{Be})$ yaitu 14,08 ton $\mathrm{m}$ dan Diasumsikan mengenai 3 fender saat kapal 60000 menabrak dermaga.

5. Beban mooring $(M)$ untuk dermaga "KNP" dilengkapi dengan bollard kapasitas 100 ton untuk mengakomodir kapal terbesar panamax 60000 DWT.

6. Beban arus $(C)$ yang diinput ke program midas gen dalam bentuk beban merata sepanjang tiang dari elevasi seabed sampai evelasi HWS yaitu sepanjang 18,8 m. Beban arus yang digunakan untuk tiang berdiameter $1200 \mathrm{~mm}$ adalah $92,55 \mathrm{~kg}$, untuk tiang berdiameter $1016 \mathrm{~mm}$ adalah 77,52 $\mathrm{kg}$, dan untuk tiang berdiameter $711 \mathrm{~mm}$ adalah $54,25 \mathrm{~kg}$.

7. Beban gantry crane $(\mathrm{Cr})$. Menggunakan 2 tipe crane yaitu crane dengan bentang 16 meter dan 22 meter, masing-masing akan diberi nama crane 1 dan crane 2 . Beban gantry crane 1 diperkirakan memiliki beban maksimum per roda sebesar 45 tonf, Sehingga besar beban crane yang bekerja adalah 45 tonf@32 roda, sedangkan beban gantry crane 2 diperkirakan memiliki beban maksimum sebesar 55 tonf, sehingga besar beban crane adalah 55 tonf@32 roda.

8. Beban gempa $(Q)$. Data digunakan merupakan hasil perhitungan gempa pada Kota Kendari Propinsi Sulawesi Tenggara dengan kondisi tanah sedang. Hasil perhitungan gempa berdasarkan aplikasi desain spektra (2021) dapat dilihat pada Tabel 3 berikut.

Tabel 3 Hasil perhitungan gempa

\begin{tabular}{cccccc}
\hline$P G A$ & 0,33 & $F a$ & 1,22 & $S D S$ & 0,58 \\
$S S$ & 0,71 & $F v$ & 2,00 & $S D 1$ & 0,28 \\
$S 1$ & 0,20 & $S M S$ & 0,88 & $T 0$ & 0,10 \\
$F P G A$ & 1,20 & $S M 1$ & 0,42 & $T s$ & 0,51 \\
\hline
\end{tabular}

(Sumber: Aplikasi desain spektra indonesia, 2021)

Kemudian data diolah dengan langkah sebagai berikut:

1. Merencanakan Model 1, 2, 3, 4, dan 5 dari tiang pancang, 
a. Model 1 dengan menghitung kedalaman titik jepit tiang pancang menggunakan metode virtual fixed point $(1 / \beta)$.

b. Model 2 dengan menghitung kedalaman titik jepit tiang pancang dengan lateral spring pada tiang pancang dengan kedalaman titik jepit tetap pada asumsi kedalaman virtual fixed point $(1 / \beta)$.

c. model 3 dengan menghitung kedalaman titik jepit tiang pancang dengan lateral spring pada tiang pancang dan perletakan nya dengan kedalaman titik jepit tetap pada asumsi kedalaman virtual fixed point $(1 / \beta)$.

d. model 4 dilakukan Permodelan struktur dengan menambahkan pegas lateral pada tiang pancang dengan interval 0,2 $\mathrm{m}$. Tiang pancang dimodelkan dengan panjang total $41 \mathrm{~m}$ dengan perletakan ujung adalah sendi.

e. model 5 dilakukan Permodelan struktur dengan menambahkan pegas lateral pada tiang pancang dengan interval 0,2 $\mathrm{m}$. Tiang pancang dimodelkan dengan panjang total $41 \mathrm{~m}$ dengan perletakan ujung adalah pegas.

2. Membuat model 1, 2, 3, 4, dan 5 yang telah direncanakan di dalam program midas gen.

3. Memasukan beban-beban sesuai dengan data perencanaan dermaga "KNP" pada program midas gen.

4. Memasukan kombinasi pembebanan pada program midas gen.

5. Menjalankan program midas untuk mengecek kekakuan dan kekuatan pada model 1, 2, 3, 4, dan 5.

6. Melakukan analisis untuk mendapatkan gaya dalam aksial dan defleksi dari masing-masing Model.

7. Membandingkan hasil analisis dari model 1, 2, 3, 4 dan 5

8. Memberikan kesimpulan dari hasil perbandingan agar mendapatkan model yang optimal.

\section{HASIL DAN PEMBAHASAN}

Hasil perhitungan virtual fixed point yang digunakan dapat dilihat pada Tabel .

Tabel 4 Virtual fixed point

\begin{tabular}{cc}
\hline Diameter tiang $(\mathrm{m})$ & Virtual fixed point di bawah seabed $(\mathrm{m})$ \\
\hline 0,711 & 3,1602 \\
1,016 & 3,9175 \\
1,2 & 4,4441 \\
\hline
\end{tabular}

Analisis yang dilakukan berupa 5 model yang diantaranya adalah model 1 dengan kedalaman $1 / \beta$, perletakan jepit dan dapat dilihat pada Gambar. Model 2 dengan kedalaman $1 / \beta$ dimodelkan pegas lateral pada tiang pancang, perletakan jepit dan dapat dilihat pada Gambar 4. Model 3 dengan kedalaman $1 / \beta$ dimodelkan pegas lateral pada tiang pancang, dimodelkan perletakan pegas dan dapat dilihat pada Gambar 5. Model 4 dengan kedalaman $41 \mathrm{~m}$ dimodelkan pegas lateral pada tiang pancang, perletakan sendi dan dapat dilihat pada Gambar 6. Model 5 dengan kedalaman $41 \mathrm{~m}$ dimodelkan pegas lateral pada tiang pancang, perletakan pegas dan dapat dilihat pada Gambar 7 .

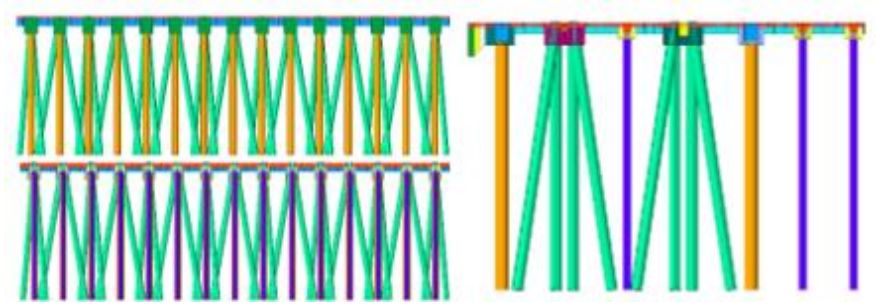

Gambar 3 Tampak depan, belakang, dan samping model 1 


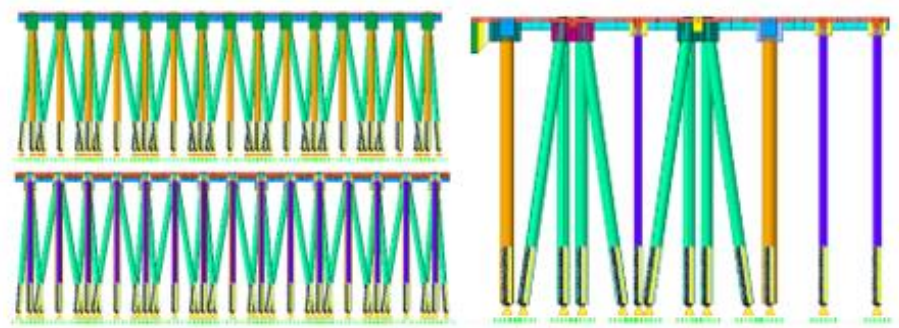

Gambar 4 Tampak depan, belakang, dan samping model 2

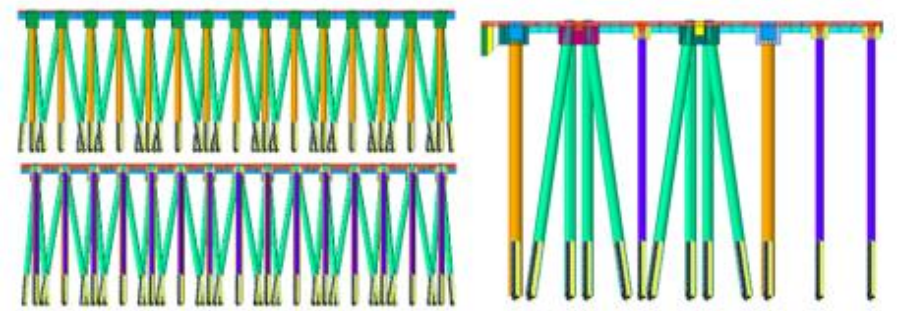

Gambar 5 Tampak depan, belakang, dan samping model 3.
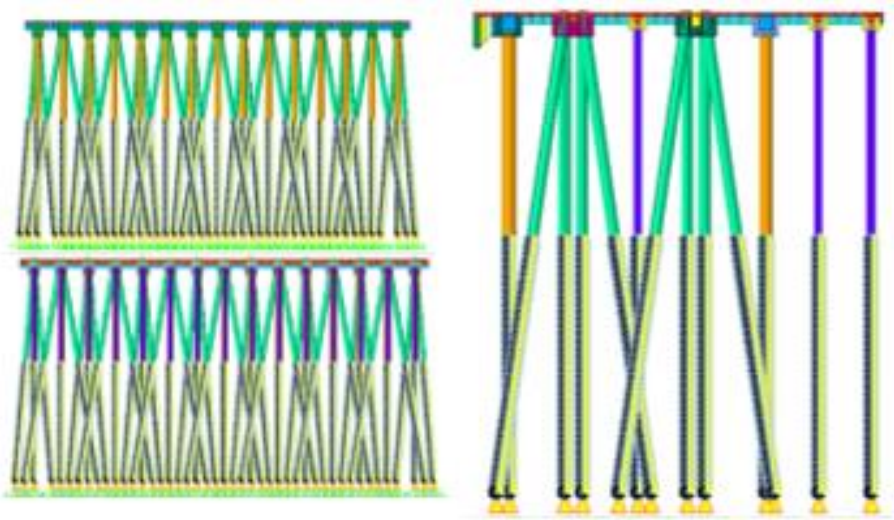

Gambar 6 Tampak depan, belakang, dan samping model 4
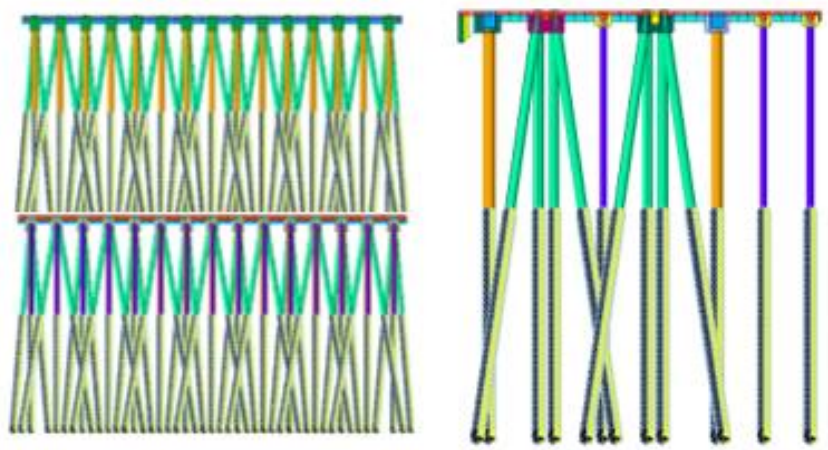

Gambar 7 Tampak depan, belakang, dan samping model 5

Kontrol terhadap capacity ratio harus dilakukan untuk menganalisis apakah tiang kuat menahan beban yang bekerja pada struktur dermaga. Nilai capacity ratio pada model 1-5 diperoleh antara 0,30-0,55. Maka dapat dikatakan model 1-5 sudah memenuhi syarat pengecekan desain kekuatan karena nilai yang diperoleh tidak lebih dari 1.

Berikut diperlihatkan grafik-grafik dari gaya aksial maksimum dari gaya tekan yang berasal dari kombinasi SDL+DL+EQ, kombinasi tersebut dipilih agar defleksi yang terjadi dapat lebih terlihat dikarenakan beban gaya lateral yang diakibatkan gaya gempa terjadi pada semua elemen secara bersamaan. Pada analisis dilakukan percobaan dengan 
menggunakan 3 jenis N-SPT, yaitu dengan nilai N-SPT dari range data minimum disimbolkan dengan A, nilai real N-SPT disimbolkan dengan B, dan nilai N-SPT dari range data maksimum disimbolkan dengan C. Range data tersebut dapat dilihat pada Tabel 2. Pada gambar 8 berikut dapat dilihat pada grafik nilai N-SPT minimum pada model 1.

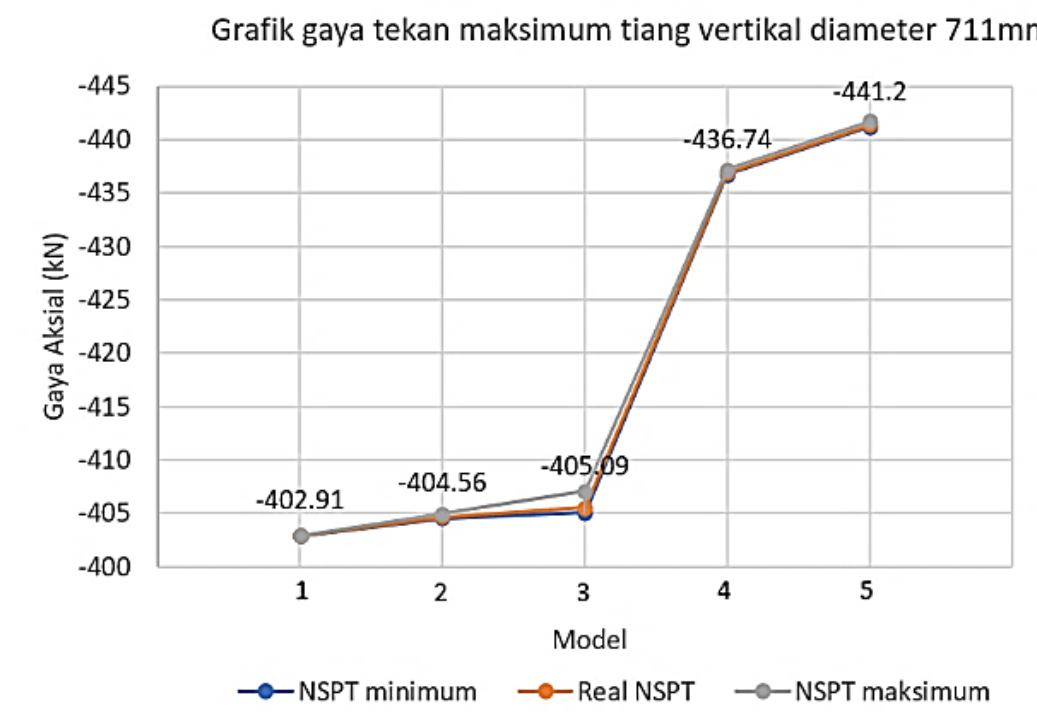

Gambar 8 Gaya tekan maksimum pada tiang diameter $711 \mathrm{~mm}$ akibat gempa

Pada gambar 8 dapat dilihat pada grafik nilai N-SPT minimum pada model 1, gaya aksial tekan pada tiang tegak dengan diameter $711 \mathrm{~mm}$ sebesar 402,91 kN. Pada saat menambahkan pegas pada batang tiang seperti model 2, gaya aksial tekan meningkat sebesar $0,41 \%$ menjadi $404,56 \mathrm{kN}$. pada saat perletakanya diubah menjadi pegas vertikal dan pegas lateral seperti pada model 3, gaya aksial tekan meningkat sebesar 0,13\% menjadi 405,09 kN. jika dilakukan pemanjangan tiang sampai pada kedalaman $41 \mathrm{~m}$ dengan perletakan sendi seperti pada model 4 , gaya aksial tekan meningkat sebesar $7,81 \%$ menjadi $436,74 \mathrm{kN}$. Jika tiang tetap pada kedalaman $41 \mathrm{~m}$ tetapi perletakanya diubah menjadi pegas lateral dan pegas vertikal seperti pada model 5, maka gaya aksial tekan yang dihasilkan meningkat sebesar $1,02 \%$ menjadi $441,2 \mathrm{kN}$.

Pada gambar 8 dapat dilihat pada grafik nilai real N-SPT pada model 1, gaya aksial tekan pada tiang tegak dengan diameter $711 \mathrm{~mm}$ sebesar 402,91 kN. pada saat menambahkan pegas pada batang tiang seperti model 2, gaya aksial tekan meningkat sebesar 0,44\% menjadi 404,69 kN. pada saat perletakanya diubah menjadi pegas seperti pada model 3 , gaya aksial tekan meningkat sebesar $0,21 \%$ menjadi $405,54 \mathrm{kN}$. jika dilakukan pemanjangan tiang sampai pada kedalaman $41 \mathrm{~m}$ dengan perletakan sendi seperti pada model 4, gaya aksial tekan meningkat sebesar 7,73\% menjadi 436,90 kN. Jika tiang tetap pada kedalaman $41 \mathrm{~m}$ tetapi perletakanya diubah menjadi pegas seperti pada model 5, maka gaya aksial tekan yang dihasilkan meningkat sebesar 1,02\% menjadi 441,37 kN.

Pada gambar 8 dapat dilihat pada grafik nilai N-SPT maksimum pada model 1, gaya aksial tekan pada tiang tegak dengan diameter $711 \mathrm{~mm}$ sebesar 402,91 kN. pada saat menambahkan pegas pada batang tiang seperti model 2, gaya aksial tekan meningkat sebesar 0,51\% menjadi 404,96 kN. Pada saat perletakanya diubah menjadi pegas seperti pada model 3, gaya aksial tekan meningkat sebesar 0,53\% menjadi 407,11 kN. Jika dilakukan pemanjangan tiang sampai pada kedalaman $41 \mathrm{~m}$ dengan perletakan sendi seperti pada model 4, gaya aksial tekan meningkat sebesar $7,40 \%$ menjadi $437,22 \mathrm{kN}$. jika tiang tetap pada kedalaman $41 \mathrm{~m}$ tetapi perletakanya diubah menjadi pegas seperti pada model 5, maka gaya aksial tekan yang dihasilkan meningkat sebesar 1,03\% menjadi 441,71 KN.

Pada gambar 9 dapat dilihat pada grafik nilai N-SPT minimum pada model 1, gaya aksial tekan pada tiang miring dengan diameter $1016 \mathrm{~mm}$ sebesar $1629,66 \mathrm{kN}$. pada saat menambahkan pegas pada batang tiang seperti model 2, gaya aksial tekan berkurang sebesar 4,21\% menjadi $1561,08 \mathrm{kN}$. Pada saat perletakanya diubah menjadi pegas seperti pada model 3, gaya aksial tekan berkurang sebesar 3,16\% menjadi 1511,83 kN. Jika dilakukan pemanjangan tiang sampai pada kedalaman $41 \mathrm{~m}$ dengan perletakan sendi seperti pada model 4, gaya aksial tekan berkurang sebesar $5,27 \%$ menjadi $1432,13 \mathrm{kN}$. Jika tiang tetap pada kedalaman $41 \mathrm{~m}$ tetapi perletakanya diubah menjadi pegas seperti pada model 5, maka gaya aksial tekan yang dihasilkan berkurang sebesar 3,17\% menjadi 1378,70 kN.

Pada gambar 9 dapat dilihat pada grafik nilai real N-SPT pada model 1, gaya aksial tekan pada tiang miring dengan diameter $1016 \mathrm{~mm}$ sebesar 1629,66 kN. pada saat menambahkan pegas pada batang tiang seperti model 2, gaya aksial tekan berkurang sebesar 4,88\% menjadi $1550,2 \mathrm{kN}$. Pada saat perletakanya diubah menjadi pegas seperti pada model 3, gaya aksial tekan berkurang sebesar 3,38\% menjadi 1497,74 kN. Jika dilakukan pemanjangan tiang sampai pada 
kedalaman 41 m dengan perletakan sendi seperti pada model 4, gaya aksial tekan berkurang sebesar 5,18\% menjadi $1420,14 \mathrm{kN}$. Jika tiang tetap pada kedalaman $41 \mathrm{~m}$ tetapi perletakanya diubah menjadi pegas seperti pada model 5 , maka gaya aksial tekan yang dihasilkan berkurang sebesar 3,76\% menjadi $1366,73 \mathrm{kN}$.

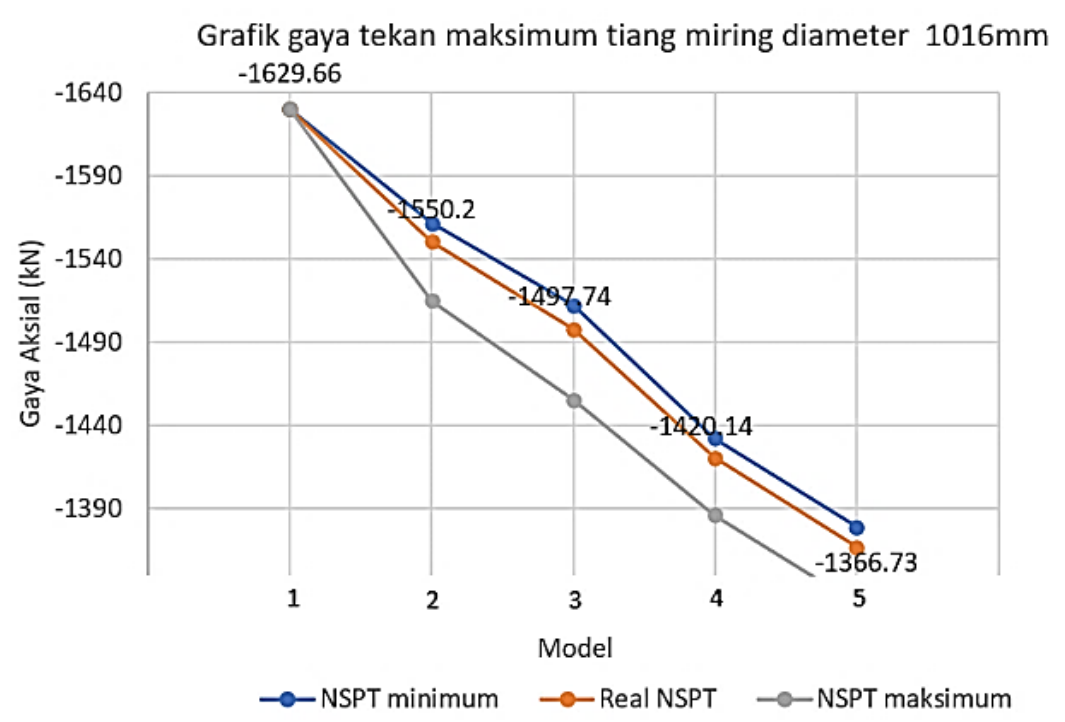

Gambar 9 Gaya aksial tekan maksimum pada tiang diameter $1016 \mathrm{~mm}$ akibat gempa

Pada gambar 9 dapat dilihat pada grafik nilai N-SPT maksimum pada model 1, gaya aksial tekan pada tiang miring dengan diameter $1016 \mathrm{~mm}$ sebesar $1629,66 \mathrm{kN}$. Pada saat menambahkan pegas pada batang tiang seperti model 2, gaya aksial tekan berkurang sebesar 7,06\% menjadi $1514,69 \mathrm{kN}$. pada saat perletakanya diubah menjadi pegas seperti pada model 3, gaya aksial tekan berkurang sebesar 3,93\% menjadi 1455,11 kN. Jika dilakukan pemanjangan tiang sampai pada kedalaman $41 \mathrm{~m}$ dengan perletakan sendi seperti pada model 4, gaya aksial tekan berkurang sebesar $4,77 \%$ menjadi $1385,73 \mathrm{kN}$. Jika tiang tetap pada kedalaman $41 \mathrm{~m}$ tetapi perletakanya diubah menjadi pegas seperti pada model 5, maka gaya aksial tekan yang dihasilkan berkurang sebesar 3,84\% menjadi 1332,46 kN. Berikut pada Gambar 10 merupakan gaya aksian tekan maksimum pada tiang diameter 1200mm akibat gempa.

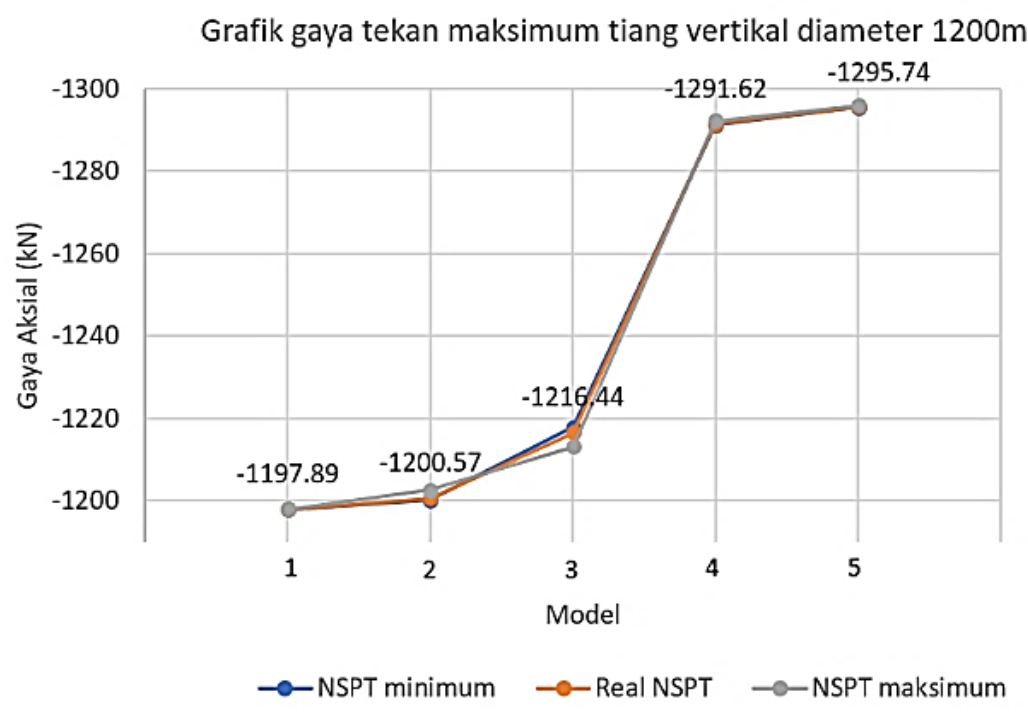

Gambar 10 Gaya aksial tekan maksimum pada tiang diameter $1200 \mathrm{~mm}$ akibat gempa

Pada gambar 10 dapat dilihat pada grafik nilai N-SPT minimum pada model 1, gaya aksial tekan pada tiang tegak dengan diameter $1200 \mathrm{~mm}$ sebesar $1197,89 \mathrm{kN}$. Pada saat menambahkan pegas pada batang tiang seperti model 2, gaya aksial tekan meningkat sebesar $0,18 \%$ menjadi $1200,03 \mathrm{kN}$. pada saat perletakanya diubah menjadi pegas seperti pada model 3, gaya aksial tekan meningkat sebesar $1,48 \%$ menjadi $1217,73 \mathrm{kN}$. Jika dilakukan pemanjangan tiang sampai pada kedalaman $41 \mathrm{~m}$ dengan perletakan sendi seperti pada model 4, gaya aksial tekan meningkat sebesar 
$6,04 \%$ menjadi $1291,28 \mathrm{kN}$. Jika tiang tetap pada kedalaman $41 \mathrm{~m}$ tetapi perletakanya diubah menjadi pegas seperti pada model 5, maka gaya aksial tekan yang dihasilkan meningkat sebesar 0,33\% menjadi 1295,54 kN.

Pada gambar 10 dapat dilihat pada grafik nilai real N-SPT pada model 1, gaya aksial tekan pada tiang tegak dengan diameter $1200 \mathrm{~mm}$ sebesar 1197,89 kN. Pada saat menambahkan pegas pada batang tiang seperti model 2, gaya aksial tekan meningkat sebesar $0,23 \%$ menjadi $1200,57 \mathrm{kN}$. Pada saat perletakanya diubah menjadi pegas seperti pada model 3 , gaya aksial tekan meningkat sebesar $1,32 \%$ menjadi $1216,44 \mathrm{kN}$. Jika dilakukan pemanjangan tiang sampai pada kedalaman $41 \mathrm{~m}$ dengan perletakan sendi seperti pada model 4, gaya aksial tekan meningkat sebesar $6,18 \%$ menjadi $1291,62 \mathrm{kN}$. Jika tiang tetap pada kedalaman $41 \mathrm{~m}$ tetapi perletakanya diubah menjadi pegas seperti pada model 5 , maka gaya aksial tekan yang dihasilkan meningkat sebesar 0,32\% menjadi $1295,74 \mathrm{kN}$.

Pada gambar 10 dapat dilihat pada grafik nilai N-SPT maksimum pada model 1, gaya aksial tekan pada tiang tegak dengan diameter $1200 \mathrm{~mm}$ sebesar 1197,89 kN. Pada saat menambahkan pegas pada batang tiang seperti model 2, gaya aksial tekan meningkat sebesar 0,40\% menjadi 1202,63 kN. Pada saat perletakanya diubah menjadi pegas seperti pada model 3, gaya aksial tekan meningkat sebesar $0,87 \%$ menjadi $1213,08 \mathrm{kN}$. Jika dilakukan pemanjangan tiang sampai pada kedalaman $41 \mathrm{~m}$ dengan perletakan sendi seperti pada model 4, gaya aksial tekan meningkat sebesar $6,53 \%$ menjadi $1292,33 \mathrm{kN}$. Jika tiang tetap pada kedalaman $41 \mathrm{~m}$ tetapi perletakanya diubah menjadi pegas seperti pada model 5, maka gaya aksial tekan yang dihasilkan meningkat sebesar 0,29\% menjadi 1296,05 kN. Berikut pada Gambar 11 dapat dilihat nilai defleksi maksimum akibat gempa arah x dan pada Gambar 12 akibat gempa arah y.

\section{Grafik Defleksi Maksimum Akibat Gempa Arah X}

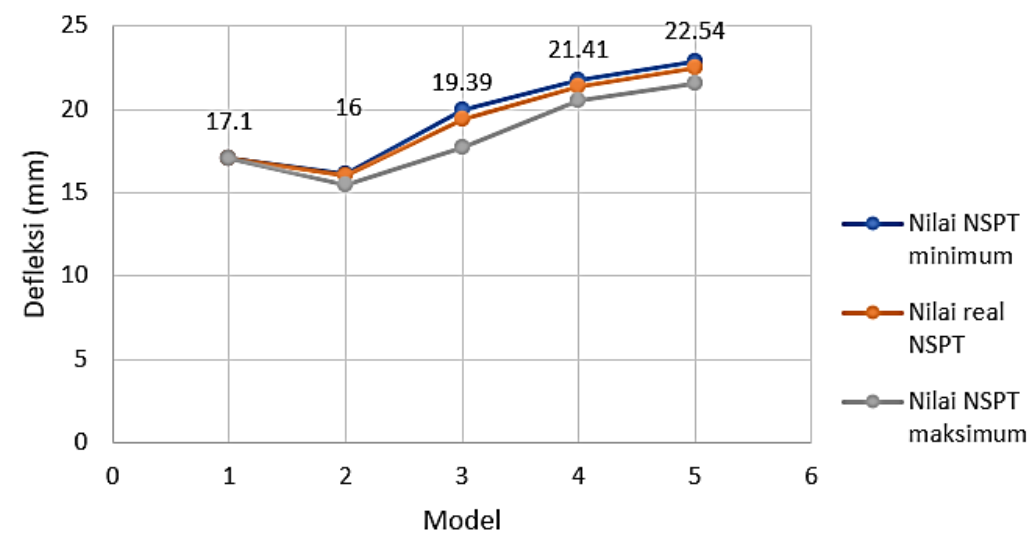

Gambar 11 Defleksi maksimum akibat gempa arah $\mathrm{x}$

Pada gambar 11 dapat dilihat pada grafik nilai N-SPT minimum model 1, defleksi terbesar yang terjadi sebesar 17,10 mm. Pada saat menambahkan pegas pada batang tiang seperti model 2, defleksi yang terjadi mengalami penurunan sebesar 5,56\% menjadi 16,15 mm. Pada saat perletakanya diubah menjadi pegas seperti pada model 3, defleksi yang terjadi meningkat sebesar 23,59\% menjadi $19,96 \mathrm{~mm}$. Jika dilakukan pemanjangan tiang sampai pada kedalaman $41 \mathrm{~m}$ dengan perletakan sendi seperti pada model 4, defleksi yang terjadi meningkat sebesar $8,87 \%$ menjadi 21,73 mm. Jika tiang tetap pada kedalaman $41 \mathrm{~m}$ tetapi perletakanya diubah menjadi pegas seperti pada model 5 , maka defleksi yang terjadi meningkat sebesar 5,34\% menjadi 22,89 mm.

Pada gambar 11 dapat dilihat pada grafik nilai real N-SPT model 1, defleksi terbesar yang terjadi sebesar 17,10 mm. pada saat menambahkan pegas pada batang tiang seperti model 2, defleksi yang terjadi mengalami penurunan sebesar $6,43 \%$ menjadi $16 \mathrm{~mm}$. Pada saat perletakanya diubah menjadi pegas seperti pada model 3, defleksi yang terjadi meningkat sebesar 21,19\% menjadi $19,39 \mathrm{~mm}$. Jika dilakukan pemanjangan tiang sampai pada kedalaman $41 \mathrm{~m}$ dengan perletakan sendi seperti pada model 4, defleksi yang terjadi meningkat sebesar 10,42\% menjadi 21,41 mm. Jika tiang tetap pada kedalaman $41 \mathrm{~m}$ tetapi perletakanya diubah menjadi pegas seperti pada model 5, maka defleksi yang terjadi meningkat sebesar 5,28\% menjadi $22,54 \mathrm{~mm}$.

Pada gambar 11 dapat dilihat pada grafik nilai N-SPT maksimum model 1, defleksi terbesar yang terjadi sebesar 17,10 mm. Pada saat menambahkan pegas pada batang tiang seperti model 2, defleksi yang terjadi mengalami penurunan sebesar 9,47\% menjadi $15,48 \mathrm{~mm}$. Pada saat perletakanya diubah menjadi pegas seperti pada model 3, defleksi yang terjadi meningkat sebesar 14,28\% menjadi 17,69 mm. Jika dilakukan pemanjangan tiang sampai pada kedalaman $41 \mathrm{~m}$ dengan perletakan sendi seperti pada model 4, defleksi yang terjadi meningkat sebesar 16,05\% menjadi $20,53 \mathrm{~mm}$. Jika tiang tetap pada kedalaman $41 \mathrm{~m}$ tetapi perletakanya diubah menjadi pegas seperti pada model 5 , maka defleksi yang terjadi meningkat sebesar 5,07\% menjadi $21,57 \mathrm{~mm}$. 


\section{Grafik Defleksi Maksimum Akibat Gempa Arah Y}

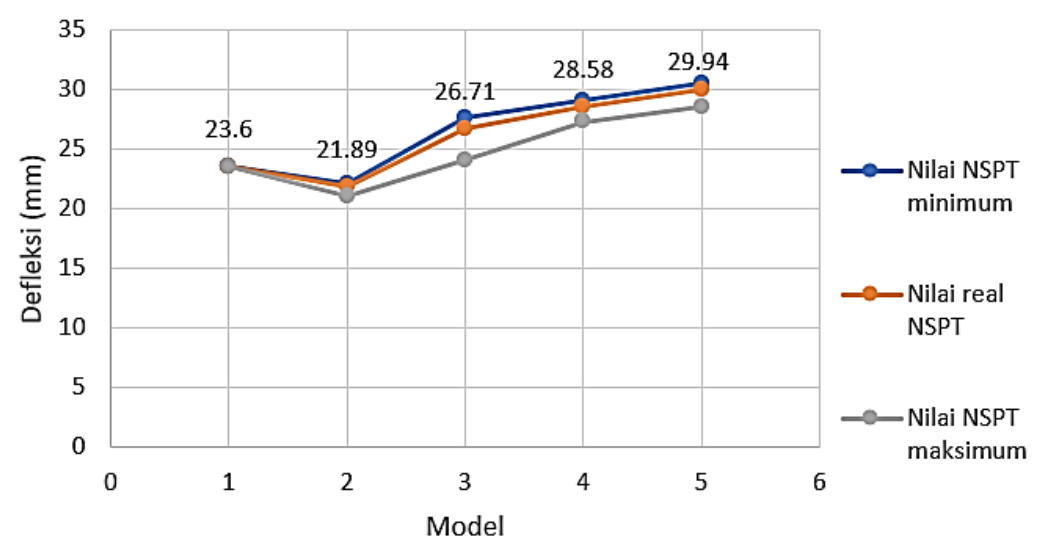

Gambar 3 Defleksi maksimum akibat gempa arah y

Pada gambar 12 dapat dilihat pada grafik nilai N-SPT minimum model 1, defleksi terbesar yang terjadi sebesar 23,60 $\mathrm{mm}$. Pada saat menambahkan pegas pada batang tiang seperti model 2, defleksi yang terjadi mengalami penurunan sebesar 6,27\% menjadi 22,12 mm. Pada saat perletakanya diubah menjadi pegas seperti pada model 3, defleksi yang terjadi meningkat sebesar 24,73\% menjadi 27,59 mm. Jika dilakukan pemanjangan tiang sampai pada kedalaman $41 \mathrm{~m}$ dengan perletakan sendi seperti pada model 4, defleksi yang terjadi meningkat sebesar 5,26\% menjadi 29,04 mm. Jika tiang tetap pada kedalaman $41 \mathrm{~m}$ tetapi perletakanya diubah menjadi pegas seperti pada model 5, maka defleksi yang terjadi meningkat sebesar 4,82\% menjadi 30,44 mm.

Pada gambar 12 dapat dilihat pada grafik nilai N-SPT real model 1, defleksi terbesar yang terjadi sebesar 23,60 mm. Pada saat menambahkan pegas pada batang tiang seperti model 2, defleksi yang terjadi mengalami penurunan sebesar $7,25 \%$ menjadi $21,89 \mathrm{~mm}$. Pada saat perletakanya diubah menjadi pegas seperti pada model 3, defleksi yang terjadi meningkat sebesar $22,02 \%$ menjadi $26,71 \mathrm{~mm}$. Jika dilakukan pemanjangan tiang sampai pada kedalaman $41 \mathrm{~m}$ dengan perletakan sendi seperti pada model 4, defleksi yang terjadi meningkat sebesar 7,00\% menjadi 28,58 mm. Jika tiang tetap pada kedalaman $41 \mathrm{~m}$ tetapi perletakanya diubah menjadi pegas seperti pada model 5, maka defleksi yang terjadi meningkat sebesar 4,76\% menjadi 29,94 mm.

Pada gambar 12 dapat dilihat pada grafik nilai N-SPT maksimum model 1, defleksi terbesar yang terjadi sebesar 23,60 mm. Pada saat menambahkan pegas pada batang tiang seperti model 2, defleksi yang terjadi mengalami penurunan sebesar $10,64 \%$ menjadi $21,09 \mathrm{~mm}$. Pada saat perletakanya diubah menjadi pegas seperti pada model 3 , defleksi yang terjadi meningkat sebesar $14,27 \%$ menjadi $24,1 \mathrm{~mm}$. Jika dilakukan pemanjangan tiang sampai pada kedalaman $41 \mathrm{~m}$ dengan perletakan sendi seperti pada model 4, defleksi yang terjadi meningkat sebesar 13,20\% menjadi $27,28 \mathrm{~mm}$. Jika tiang tetap pada kedalaman $41 \mathrm{~m}$ tetapi perletakanya diubah menjadi pegas seperti pada model 5 , maka defleksi yang terjadi meningkat sebesar 4,55\% menjadi $28,52 \mathrm{~mm}$.

Hasil perbandingan kedalaman titik jepit dengan menggunakan metode virtual fixed point dan lateral spring memiliki perbedaan selisih sebesar $\pm 6,73 \%$ dengan kedalaman untuk metode virtual fixed point $-24 \mathrm{~m}$ dari dek dermaga dan untuk lateral spring dengan menggunakan standar deviasi diperoleh sebesar -25,62 m dari dek dermaga

\section{KESIMPULAN DAN SARAN}

Setelah melakukan simulasi desain struktur dermaga dan dilakukan analisis perbandingan kedalaman titik jepit dan defleksi pada masing-masing model, maka kesimpulan yang dapat diambil adalah:

1. Analisis kedalaman titik jepit dengan menggunakan metode virtual fixed point $(1 / \beta)$ adalah $-24 \mathrm{~m}$ dari dek dermaga.

2. Metode virtual fixed point dapat digunakan pada permodelan ini karena defleksi lateral dan rotasi yang terjadi pada fixed point sudah sangat kecil dan dapat diabaikan.

3. Analisis dengan model 4 dan 5, kedalaman titik jepit dengan menggunakan lateral spring adalah $-25,62$ m dengan selisih $\pm 6,73 \%$ dari dek dermaga.

4. Hasil analisis pada model 1, 2, 3, 4, dan 5, model yang menghasilkan defleksi terkecil adalah model 2 dengan besaran nilai defleksi arah x sebesar $16,15 \mathrm{~mm}$ dan untuk arah y sebesar 22,12 $\mathrm{mm}$. 
5. Analisis dengan menambahkan lateral spring pada tiang pancang dapat menjadikan model lebih optimal karena membuat defleksi lebih kecil sebesar 6,43\% untuk arah x dan 7,25\% untuk arah y.

6. Analisis yang dilakukan dengan menggunakan nilai N-SPT minimum, nilai real N-SPT, dan nilai N-SPT maksimum, hasil pada grafik defleksi yang diperoleh menunjukan selisih perbedaan defleksi maksimum untuk arah x sebesar $8,77 \%$ dan untuk arah y sebesar $9,77 \%$.

7. Analisis yang dilakukan dengan menggunakan nilai N-SPT minimum, nilai real N-SPT, dan nilai N-SPT maksimum, hasil pada grafik gaya aksial yang diperoleh menunjukan selisih perbedaan maksimum untuk tiang dengan diameter $711 \mathrm{~mm}$ sebesar 0,39\%, diameter $1016 \mathrm{~mm}$ sebesar 2,85\%, dan diameter $1200 \mathrm{~mm}$ sebesar $0,28 \%$.

Saran yang diusulkan setelah melakukan penelitian ini adalah melakukan penelitian lebih lanjut menggunakan lateral spring yang lain dengan kemiringan horizontal sebesar $30^{\circ}, 60^{\circ}, 90^{\circ}$ dan kemiringan vertikal tiang yang berbeda.

\section{DAFTAR PUSTAKA}

Apriliawati, A. A. (2017). Perancangan Detail Perkuatan Struktur Bawah Pasca Pelaksanaan Jembatan Cidano Jalan Tol Soreang-Pasir Koja. Perpustakaan Digital Politeknik Negeri Bandung, II-37.

Badan Standardisasi Nasional. (2019). SNI 1726:2019 Tata cara perencanaan ketahanan gempa untuk struktur bangunan gedung dan nongedung. Standar Nasional Indonesia.

Bowles, J. E. (1997). Foundation Analysis and Design.

DAS, B. (2011). Principle of Foundation Enggineering.

Desain Spektra Indonesia. (2021, 04 18). Diambil kembali dari www.pu.go.id

Gustinara, A. (2013). Analisis Perbaikan Struktur Dermaga dengan Bresing. FT UI.

Irawati, N. (2019). Perencanaan Pelabuhan. Jakarta: Indeks Jakarta.

NAVFAC. (1971). Design Manual: Soil Mechanics, Foundation and Earth Structures. US: Naval Publications and Forms Center.

Sulardi. (2018). Perbaikan dan Proteksi Pondasi Tiang Dermaga Dengan Metode Pile Encapsulation. Borneo Engineering: Jurnal Teknik Sipil, 15.

The Overseas Coastal Area Development Institute of Japan. (2002). Techical Standards and Commentaries for Harbour Facilities in Japan. Tokyo: The Overseas Coastal Area Development Institute of Japan.

Triatmodjo, B. (2010). Perencanaan Pelabuhan. Yogyakarta: Beta Offset Yogyakarta. 